\title{
Body composition changes in goats during early lactation estimated using a two-pool model of tritiated water kinetics
}

\author{
BY F. R. DUNSHEA* AND A. W. BELL†\$ \\ School of Agriculture, La Trobe University, Bundoora, Victoria 3083, Australia \\ AND T. E. TRIGG $\ddagger$ \\ Animal and Irrigated Pastures Research Institute, Kyabram, Victoria 3620, Australia
}

(Received 16 May 1989 - Accepted 5 February 1990)

\begin{abstract}
A two-pool model of tritiated water kinetics was used to estimate the major body water pools, and hence body composition, in goats at days 10,38 and 76 of lactation. Between days 10 and 38 of lactation goats were, on average, in negative calculated energy balance and were estimated to have mobilized $59 \mathrm{~g}$ body fat stores/d. Mean calculated energy balance over days 38-76 of lactation was slightly positive and there was little change in estimated body fat. Gut fill increased over the early part of lactation when goats were mobilizing body fat. Consequently, live weight did not differ at any stage of lactation and did not provide a good index of body fat status of the goats. There were also no significant differences in empty-bodyweight, water, protein, ash or fat-free mass at the three stages of lactation. As average calculated energy balance and changes in energy stored as fat were highly correlated, it is concluded that the two-pool model of tritiated water kinetics is a useful means of serially estimating changes in body fat content in unfasted lactating goats.
\end{abstract}

Body composition: Fat mobilization: Lactation: Goat

In ruminants, feed intake increases gradually during the early post-partum period and does not become maximal until several weeks after peak milk yield is attained (Bines, 1979). In order to maintain milk production to their genetic potential, animals often mobilize considerable amounts of body fat during early lactation.

Much of our knowledge on the extent to which these reserves are relied on has been obtained using the comparative slaughter technique (Cowan et al. 1980 a, 1981). However, this technique precludes serial measurements in individual animals. A promising alternative for quantifying changes in body composition in individual animals is the measurement of body water by isotope dilution (Panaretto \& Till, 1963; Foot \& Greenhalgh, 1970; Searle, 1970), particularly when associated with compartmental analysis to separate the major body water pools (Robelin, 1977; Byers, 1979). Recently, we have used this approach to relate body composition to live weight and tritiated water (TOH) kinetics in lactating goats (Dunshea et al. 1988a). The technique was also applied to study fat mobilization during the first 10 weeks of lactation in primiparous goats (Dunshea et al. 1989).

The aim of the present study was to extend our earlier studies and use TOH kinetics to investigate changes in body composition of well-fed multiparous goats during early lactation. In addition the animals were divided into two treatment groups, with one group receiving intravenous arginine and the other saline $(9 \mathrm{~g}$ sodium chloride/1) for $7 \mathrm{~d}$ pre-

Present addresses: * Animal Research Institute, Werribee, Victoria 3030, Australia $\uparrow$ Department of Animal Science, Cornell University, Ithaca, NY 14853, USA. $¥$ Peptide Technology, PO Box 444, Dee Why, NSW 2099, Australia.

$\S$ For reprints. 
partum. Intravenous injection of arginine pre-partum has been shown to increase milk production in dairy cows (Chew et al. 1984), possibly through altering the hormonal status of the animals. For example, intravenous injection of arginine acutely increases circulating concentrations of somatotropin, prolactin, placental lactogen and insulin, some of which may be lactogenic (Chew et al. 1984).

\section{MATERIALS AND METHODS}

\section{Animal treatments, feeding and preparation}

Twelve multiparous Saanen does, aged 3-6 years and weighing $44-62 \mathrm{~kg}$, were used. Mating dates for eight of the goats were recorded using a Sire-sine harness (Hortico, Australia) while those of the other goats were given by the breeders from whom they were purchased. Goats were paired on the basis of live weight and previous milk production, and one of each pair allocated to either the saline- (S) or arginine- (A) infusion group.

At 2 months before parturition all goats were taken off pasture and brought inside and offered ad lib. chopped lucerne (Medicago sativa) hay once daily. At 1 month before parturition chopped lucerne-whole oats (Avena sativa) $(80: 20, \mathrm{w} / \mathrm{w})$ were offered ad lib. in two equal portions at 09.00 and 16.30 hours. After parturition all goats received $a d$ lib. a diet of lucerne hay-whole oats-rolled lupins (Lupinus albus) $(65: 25: 10$, by wt). Feed was offered twice daily except for the $4 \mathrm{~d}$ before and until $1 \mathrm{~d}$ after the TOH injection. During this time the goats were fed every $2 \mathrm{~h}$ via a belt-driven automatic feeding system. The lactation diet contained $182 \mathrm{~g}$ crude protein (nitrogen $\times 6.25$ ) and $10.0 \mathrm{MJ}$ metabolizable energy (ME)/kg dry matter. ME content was estimated from the apparent digestibility of organic matter (Ministry of Agriculture, Fisheries and Food, 1975) determined in eight of the does during the 8 th week of lactation. Dry matter, organic matter and $\mathrm{N}$ digestibilities were $0.664,0.665$ and 0.759 respectively. At $8 \mathrm{~d}$ before expected parturition each goat was fitted with a jugular venous catheter as outlined later. Goats received either arginine $(300 \mathrm{~g} / 1,0.5 \mathrm{~g} / \mathrm{kg}$ live weight) or physiological saline $(1.6 \mathrm{ml} / \mathrm{kg}$ live weight) each day at 11.00 hours, $2 \mathrm{~h}$ after the morning feeding, until kidding at which time the catheters were removed. Solutions were filtered through $0.22 \mu \mathrm{m}$ disposable filters (Millex-GS; Millipore, USA) and infused via the jugular catheter over $10 \mathrm{~min}$. Kids were removed immediately after parturition and the does were then machine-milked. Thereafter, goats were milked twice daily at approximately 08.00 and 16.00 hours. On the day before and on the day of an experiment, portions of milk were obtained at each milking and analysed for lactose, fat and protein concentrations using an infra-red milk analyser (Milkoscan; Foss, Switzerland).

Polyethylene catheters $(0.80 \mathrm{~mm}$ i.d., $1.20 \mathrm{~mm}$ o.d.; Dural Plastics, NSW, Australia) were inserted at least $30 \mathrm{~h}$ before an experiment. As non-esterified fatty acid (NEFA) and glycerol kinetics were determined before TOH kinetics (Dunshea et al. 1990), extra catheters were required. In nine goats which had been surgically prepared with carotid loops (Hecker, 1974) at least 2 months before parturition, the infusion and sampling catheters were inserted $15 \mathrm{~cm}$ into a jugular vein and common carotid artery respectively. In the remaining three goats the sampling catheter was positioned in the right ventricle via the jugular vein contralateral to that containing the infusion catheter (Linzell, 1966).

\section{Measurements}

TOH kinetics. TOH kinetic measurements were made three times during lactation, at 10 (SE 0.5), 38 (SE 1.1) and 76 (SE 2.1) d post-partum. These measurements were preceded by kinetic studies of NEFA and glycerol utilizing unprimed simultaneous continuous 
infusions of $\left[1-{ }^{14} \mathrm{C}\right] \mathrm{NEFA}$ and $\left[2-{ }^{3} \mathrm{H}\right]$ glycerol as tracers (Dunshea et al. 1990). As [2${ }^{3} \mathrm{H}$ ]glycerol can be oxidized to yield $\mathrm{TOH}$, the $\mathrm{TOH}$ kinetic measurements were not commenced until $4 \mathrm{~h}$ after the termination of the continuous infusions to allow for complete mixing of metabolic $\mathrm{TOH}$ with total body water (TBW). The tritium remaining in the dry matter of deproteinized supernatant fractions obtained from blood samples taken at this time was negligible. Preliminary experiments demonstrated that the rateconstant describing the disappearance of TOH from the body during the period 4-24 h after infusion of $\left[2-{ }^{3} \mathrm{H}\right]$ glycerol was not different from that $4-24 \mathrm{~h}$ after injection of TOH. This confirms that recycling of tritium after $\left[2{ }^{3} \mathrm{H}\right]$ glycerol infusion does not influence subsequent determinations of $\mathrm{TOH}$ kinetics.

Immediately before TOH injection the goats were milked, induced to urinate (Corbett et al. 1971) and then weighed. After obtaining a blood sample to determine residual TOH specific radioactivity (SRA), a single dose of TOH ( $5 \mathrm{Ci} / 1$; Amersham International plc, Amersham, Bucks) diluted in saline $(30 \mathrm{mCi} / \mathrm{l})$ was injected via the jugular catheter $(10 \mu \mathrm{Ci} / \mathrm{kg})$ and followed immediately by $20 \mathrm{ml}$ sterile saline. The TOH dose ensured a plasma TOH SRA at 15 min post-injection at least four times that observed in the preinjection samples. Jugular blood samples were taken at 15, 20, 25, 30, 37, 45, 55, 80, 120 , $180,300,480,720,1080$ and 1440 min post-injection. TOH SRA was obtained by liquidscintillation counting of duplicate $0.5 \mathrm{ml}$ samples of plasma water obtained by lyophilization.

After the final blood sample on day 77 of lactation, goats were slaughtered and chemical body composition determined (Dunshea et al. 1988a).

Calculations and statistics. The TOH SRA $v$. time curve was fitted to a second-order exponential decay function (Shipley \& Clark, 1972; Byers, 1979) using the maximum likelihood program (MLP; Ross, 1980). In this model water enters into gastrointestinal tract water (GW, pool B) and leaves from empty-body (EB) water (EBW; pool A) as either urine, milk or insensible loss. There is also a small loss from GW via faeces. TOH pool sizes were calculated by dividing the $\mathrm{TOH}$ dose by the two zero-time intercepts of the decay function. TBW was calculated from the intercept of the slow turnover component of the decay curve (pools $\mathrm{A}+\mathrm{B}, \mathrm{T}$ ) and $\mathrm{EBW}$ from the intercept of the rapidly equilibrating component of the decay curve (pool A). Pool B, putatively GW, was calculated by difference. Body composition was estimated from $\mathrm{TOH}$ pool sizes using the equations from Dunshea et al. $(1988 a)$ and summarized in Table 1. These equations were derived from observations on seventeen lactating goats, including the ten goats which completed the present study.

Maintenance energy requirements were assumed to be $0.312 \mathrm{MJ} \mathrm{ME} / \mathrm{kg}$ live weight ${ }^{0.75}$ per $\mathrm{d}$ (Armstrong \& Blaxter, 1965). Milk energy was calculated from the fat, protein and lactose contents of milk using equation 1 from Tyrrell \& Reid (1965). The partial efficiency of conversion of ME to milk energy $\left(k_{1}\right)$ was assumed to be 0.62 (Agricultural Research Council, 1980). Energy balance was calculated as ME intake less ME for maintenance and milk production.

Statistical and regression analyses were performed using Minitab version 5.1 (Ryan et al. 1985) and Statistical Analysis System (1982; SAS). Stage of lactation effects were assessed using analysis of variance with goat and stage of lactation being the main effects and the interaction being the error term.

\section{RESULTS}

Production. Two goats (one from each group) became ill and were removed from the study at approximately 3 weeks post-partum; no values from these animals are included. During the first 10 weeks of lactation milk production of group A averaged $2.56(\mathrm{SE} 0.39) \mathrm{kg} / \mathrm{d}$ and 
Table 1. Regression equations used to predict total body water (TBW), empty-body water $(E B W)$, gut water $(G W)$, gut fill $(G F)$, empty-body-weight (EWT), empty-body fat $(E B F)$, empty-body protein (EBP), empty-body ash $(E B A)$ and fat-free empty body (FFEB) from live weight (LWT), tritiated-water $(T O H)$ pool $A(A), T O H$ pool $B(B)$, the sum of TOH pools $A$ and $B(T)$, dry matter intake $(D M I)$, predicted $G F\left(G F^{*}\right)$ and predicted $E W T\left(E W T^{*}\right)$ in lactating goats (from Dunshea et al. 1988a)

\begin{tabular}{|c|c|c|c|c|c|c|c|c|c|c|}
\hline \multirow[b]{2}{*}{ Component } & \multirow{2}{*}{$\begin{array}{c}\text { Equation } \\
\text { no. }\end{array}$} & \multirow[b]{2}{*}{ Model } & \multirow[b]{2}{*}{$a$} & \multicolumn{2}{|l|}{$b_{1}$} & \multicolumn{2}{|l|}{$b_{2}$} & \multirow{2}{*}{$\begin{array}{l}\text { RSD } \\
(\mathrm{kg})\end{array}$} & \multirow{2}{*}{$\begin{array}{l}\mathrm{RCV} \\
(\%)\end{array}$} & \multirow[b]{2}{*}{$r$} \\
\hline & & & & Coefficient & SE & Coefficient & $\mathrm{SE}$ & & & \\
\hline TBW (kg) & 1 & $a+b_{1} \mathbf{T}$ & $0 \cdot 300$ & 0.892 & 0.0376 & & & 1.02 & $3 \cdot 4$ & 0.987 \\
\hline EBW (kg) & 2 & $a+b_{1} \mathrm{~A}$ & $-0 \cdot 101$ & 0.929 & $0-0464$ & & & 0.90 & $4 \cdot 1$ & 0.982 \\
\hline GW (kg) & 3 & $a+b_{1} \mathrm{~B}$ & $2 \cdot 51$ & 0.575 & 0.0733 & & & $0 \cdot 86$ & $10 \cdot 9$ & 0.897 \\
\hline $\mathrm{GF}(\mathrm{kg})$ & 4 & $a+b_{1} \mathrm{~B}+b_{2} \mathrm{DMI}$ & 0.982 & 0.531 & 0.0698 & $2 \cdot 03$ & 0.479 & 0.73 & $7 \cdot 8$ & 0.951 \\
\hline EWT (kg) & 5 & $a+b_{1}\left(\mathrm{LWT}-\mathrm{GF}^{*}\right)$ & -0.279 & 0.996 & 0.0387 & & & 1.01 & $2 \cdot 7$ & 0.992 \\
\hline EBF (kg) & 6 & $a+b_{1} \mathrm{EWT}^{*}+b_{2} \mathrm{~A}$ & $-0 \cdot 198$ & 0.866 & 0.0971 & $-1 \cdot 01$ & 0.158 & 1.09 & $13 \cdot 2$ & 0.941 \\
\hline $\mathrm{EBF}(\mathrm{kg})$ & 7 & $a+b_{1}^{2} \mathrm{LWT}+b_{22}^{2} \mathrm{~T}$ & -0.932 & $0 \cdot 809$ & $0 \cdot 109$ & $-0 \cdot 867$ & $0 \cdot 150$ & $1 \cdot 33$ & $16 \cdot 1$ & 0.911 \\
\hline EBP (kg) & 8 & $a+b_{1} \mathrm{~T}$ & $-0 \cdot 323$ & $0 \cdot 175$ & 0.0221 & & & 0.63 & $11 \cdot 4$ & $0 \cdot 887$ \\
\hline EBA $(\mathrm{kg})$ & 9 & $a+b_{1}$ LWT & $0 \cdot 204$ & 0.027 & 0.0033 & & & $0 \cdot 12$ & $8 \cdot 2$ & 0.906 \\
\hline FFEB (kg) & 10 & $a+b_{1} \mathrm{LWT}+b_{2} \mathrm{~A}$ & -0.952 & $0 \cdot 262$ & $0 \cdot 122$ & $0 \cdot 740$ & $0 \cdot 233$ & $1 \cdot 31$ & $4 \cdot 5$ & 0.979 \\
\hline
\end{tabular}

RSD, residual standard deviation; RCV, residual coefficient of variation.

that of group S, 1.86 (SE 0.22$) \mathrm{kg} / \mathrm{d}$. However, group A had a greater incidence of twin births (four of six) compared with group $\mathrm{S}$ (two of six). Because goats giving birth to twins generally produce more milk than those having single births (Steine, 1975), and the effects of number of offspring on any variable could not be statistically separated from the effects of pre-partum arginine, all values were pooled across groups.

Milk production tended to increase over the first 3-4 weeks of lactation and gradually declined from about 7 weeks to the cessation of the study at 10 weeks post-partum (Fig. 1). Mean peak milk production was 2.42 ( $\mathrm{SE} 0.13) \mathrm{kg} / \mathrm{d}$ between weeks 5 and 7 of lactation. Yield and concentration of fat, protein and lactose in milk all decreased as lactation advanced (Table 2).

Dry matter intake. Dry matter intake (DMI) increased during early lactation, peaking at about week 8 of lactation (Fig. 1). DMI was significantly lower at day 10 of lactation than at either of the other times when body composition was estimated (Table 2).

Energy balance. Calculated energy balance increased during the first 10 weeks of lactation (Fig. 1, Table 2) with the average energy balance reaching zero at about 5 weeks post-partum. Average energy balances between days 10 and 38 and days 38 and 76 were -2.54 (SE 0.57) and 0.96 (SE 0.57) MJ ME/d respectively.

Body composition. Live weight and estimates of body composition are given in Table 3 . Live weights were remarkably similar at each stage of lactation, as were estimates of EBW, EB protein, EB ash and the fat-free EB (Table 3). Also, EB fat estimated using the one-pool model of TOH kinetics (Table 1, equation 7) was not different at any stage of lactation, being $9 \cdot 83,9 \cdot 32$ and $9 \cdot 60$ at days 10,38 and 76 post-partum respectively.

However, EB fat estimated using the two-pool model of TOH kinetics (Table 1, equations 4, 5 and 6) was significantly lower at day 38 than at day 10 of lactation (Table 3). During the interim period mean EB fat loss was 59 (SE 18) $\mathrm{g} / \mathrm{d}$ (range -23 to $172 \mathrm{~g} / \mathrm{d}$ ). There was no change in mean EB fat estimated in this manner between days 38 and 76 of lactation. Changes in tissue energy in the form of fat, as estimated with the two-pool model, were of the same magnitude and related to average calculated energy balance between times of estimation of body composition (Fig. $2 ; r 0.687, P<0.01$ ). The regression describing this 


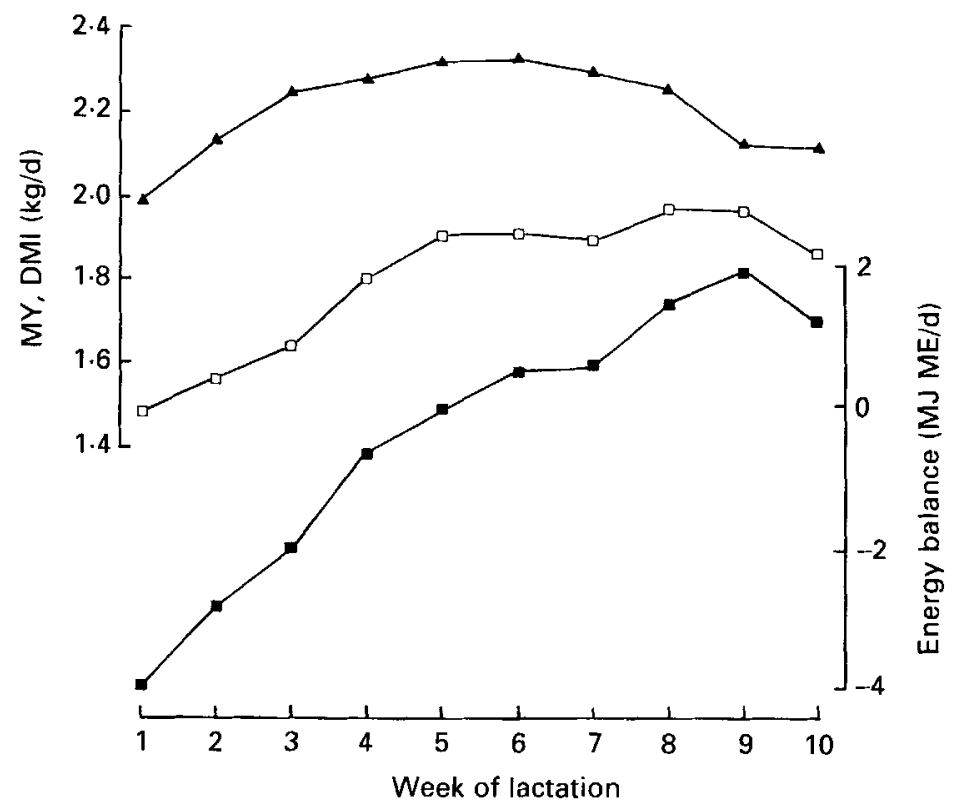

Fig. 1. Mean daily milk yield (MY; $\Delta$ ), dry matter intake (DMI; $\square$ ) and calculated energy balance ( $\square$ ) measured over weekly intervals in ten lactating goats during the first 10 weeks of lactation. ME, metabolizable energy.

Table 2. Milk yield and components, calculated energy balance and dry matter intake for ten lactating goats at three stages of lactation

\begin{tabular}{|c|c|c|c|c|}
\hline & Mean & Meàn & Mean & $\begin{array}{c}\text { Pooled SE } \\
\text { (18 df }\end{array}$ \\
\hline Day of lactation... & 10 & 38 & 76 & \\
\hline Milk yield $(\mathrm{kg} / \mathrm{d})$ & $2 \cdot 25^{\mathrm{ab}}$ & $2 \cdot 35^{\mathrm{b}}$ & $2 \cdot 06^{\mathrm{a}}$ & $0 \cdot 136$ \\
\hline \multicolumn{5}{|l|}{ Milk fat } \\
\hline $\mathrm{g} / \mathrm{d}$ & $105^{\mathrm{a}}$ & $92 \cdot 0^{\mathrm{a}}$ & $72 \cdot 0^{\mathrm{b}}$ & 6.04 \\
\hline $\mathrm{g} / \mathrm{kg}$ & $47 \cdot 3^{\mathrm{a}}$ & $39 \cdot 2^{\mathrm{h}}$ & $34 \cdot 6^{\mathrm{C}}$ & 1.45 \\
\hline \multicolumn{5}{|l|}{ Milk protein } \\
\hline $\mathrm{g} / \mathrm{d}$ & $67 \cdot 6^{\mathrm{a}}$ & $60 \cdot 9^{a}$ & $50 \cdot 8^{\circ}$ & 3.85 \\
\hline $\mathrm{g} / \mathrm{kg}$ & $30 \cdot 0^{\mathrm{a}}$ & $26 \cdot 3^{\mathrm{ab}}$ & $24 \cdot 8^{b}$ & 0.71 \\
\hline \multicolumn{5}{|l|}{ Milk lactose } \\
\hline $\mathrm{g} / \mathrm{d}$ & $111 \cdot 2^{\mathrm{a}}$ & $113 \cdot 4^{\mathrm{a}}$ & $94 \cdot 6^{b}$ & $6 \cdot 26$ \\
\hline $\mathrm{g} / \mathrm{kg}$ & $49 \cdot 6$ & $48 \cdot 5$ & $46 \cdot 2$ & $0 \cdot 382$ \\
\hline Energy balance (MJ ME/d) & $-4 \cdot 92^{a}$ & $-0 \cdot 16^{b}$ & $1.70^{\mathrm{c}}$ & 0.653 \\
\hline Dry matter intake $(\mathrm{kg} / \mathrm{d})$ & $1 \cdot 35^{\mathrm{a}}$ & $1 \cdot 72^{b}$ & $1.69^{\mathrm{b}}$ & 0.065 \\
\hline
\end{tabular}

ME, metabolizable energy.

a,b.e. Mean values in the same row with different superscript letters were significantly different $(P<0 \cdot 05)$.

relationship was very close to the expected value based on respective partial efficiencies of energy use in the lactating dairy cow of $0.64,0.75$ and 0.82 for conversion of ME to milk energy, ME to tissue energy and tissue energy to milk energy (Moe, 1981).

During the period days 10-39 post-partum, gut fill (GF), as predicted by DMI and pool B, increased by $0.92 \mathrm{~kg}(P<0.05)$. GF did not change between days 38 and 76 of lactation. TOH kinetics. Water turnover was significantly greater at day 38 than at either days 10 
Table 3. Body composition and water turnover estimated from live weight and tritiated water pools in ten lactating goats at three stages of lactation*

\begin{tabular}{|c|c|c|c|c|}
\hline & Mean & Mean & Mean & $\begin{array}{l}\text { Pooled SE } \\
\text { (18 df) }\end{array}$ \\
\hline Day of lactation... & 10 & 38 & 76 & \\
\hline Live wt $(\mathrm{kg})$ & $52 \cdot 9$ & $52 \cdot 8$ & 53.6 & $1 \cdot 30$ \\
\hline Empty-body-wt $(\mathrm{kg})$ & $43 \cdot 2$ & $42 \cdot 3$ & $42 \cdot 9$ & 1.00 \\
\hline Empty-body water (kg) & 23.8 & $24 \cdot 6$ & $24 \cdot 8$ & $0 \cdot 62$ \\
\hline Empty-body fat $(\mathrm{kg})$ & $11 \cdot 2^{a}$ & $9 \cdot 57^{\mathrm{b}}$ & $9 \cdot 99^{\mathrm{ab}}$ & 0.617 \\
\hline Empty-body protein $(\mathrm{kg})$ & $6 \cdot 12$ & $6 \cdot 24$ & $6 \cdot 32$ & $0 \cdot 127$ \\
\hline Empty-body ash (kg) & 1.63 & $1 \cdot 60$ & 1.61 & $0 \cdot 031$ \\
\hline Fat-free empty body $(\mathrm{kg})$ & $31 \cdot 2$ & $32 \cdot 5$ & $32 \cdot 9$ & 0.72 \\
\hline Gut fill $(\mathrm{kg})$ & $9 \cdot 68^{a}$ & $10 \cdot 6^{b}$ & $10 \cdot 6^{\mathrm{b}}$ & $0 \cdot 25$ \\
\hline Tritiated water pool $\mathbf{A} \dagger(\mathrm{kg})$ & $25 \cdot 7$ & $26 \cdot 5$ & 16.8 & 0.665 \\
\hline Tritiated water pool $\mathrm{B} \dagger(\mathrm{kg})$ & 106 & $11 \cdot 1$ & $11 \cdot 1$ & $0 \cdot 35$ \\
\hline Water turnover $(\mathrm{kg} / \mathrm{d})$ & $5 \cdot 80^{\mathrm{a}}$ & $8 \cdot 17^{b}$ & $5 \cdot 10^{\mathrm{a}}$ & 0.426 \\
\hline
\end{tabular}

${ }^{a, b}$ Mean values in the same row with different superscript letters were significantly different $(P<0.05)$.

* Body composition predicted from the equations in Table 1.

$\dagger$ Pools A and B represent empty-body water and gastrointestinal tract water, respectively (see Calculations and statistics).

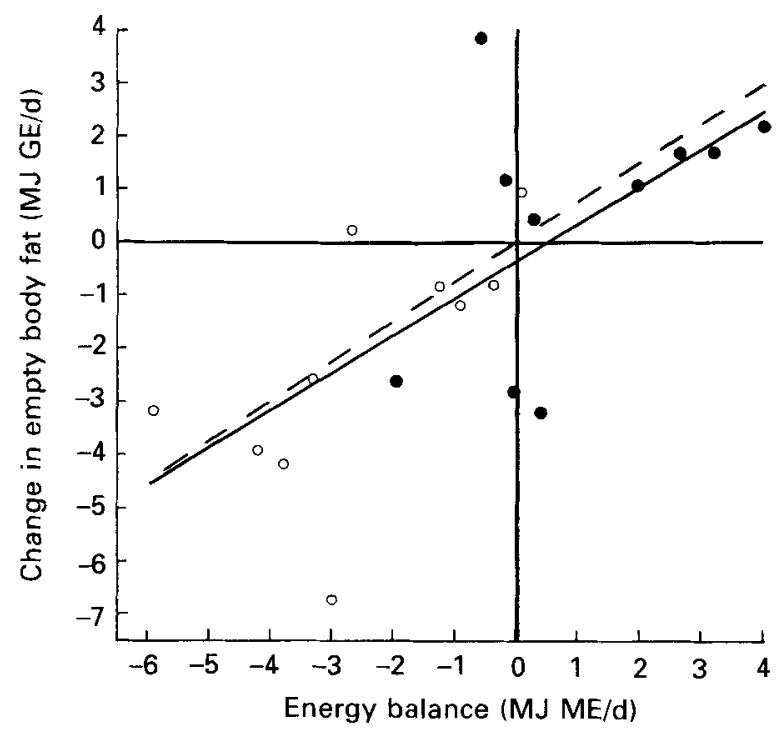

Fig. 2. Change in empty-body fat (MJ gross energy (GE)/d), predicted from estimated body composition $v$. average calculated energy balance (MJ metabolizable energy (ME)/d) in ten lactating goats between days 10 and $38(0)$ and between days 38 and $76(0)$ of lactation.

( - $Y=-0.38+0.711 X ; r 0.687)$. (---), Expected relationship based on respective partial efficiencies of energy use of $0.64,0.75$ and 0.82 for conversion of ME to milk energy, ME to tissue energy and of tissue energy to milk energy (Moe, 1981).

or 76 of lactation (Table $3 ; P<0.05$ ). Whole-body TOH space estimated using the kinetic model was lower than that estimated by measuring the dilution of TOH in a blood sample taken $6 \mathrm{~h}$ post-injection (Fig. 3). The correlation between the two estimates of TBW was highly significant $(r 0.952, P<0.001)$ although the residual standard deviation (RSD) was relatively large $(1.42 \mathrm{~kg})$. 


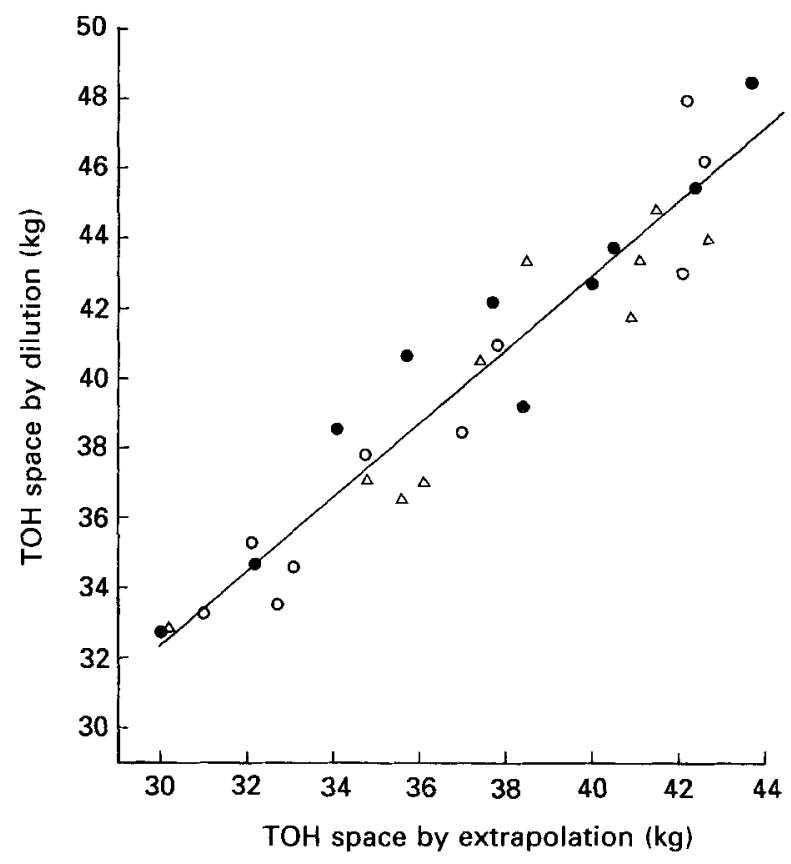

Fig. 3. Relationship between tritiated water (TOH) space determined by dilution in a plasma sample taken $6 \mathrm{~h}$ post-injection and $\mathrm{TOH}$ space determined by extrapolation at day $10(\mathrm{O}), 38(O)$ and $76(\triangle)$ of lactation $(Y=0.546+1.06 X ; r 0.953)$.

\section{DISCUSSION}

Most studies of fat mobilization during early lactation have used either comparative slaughter techniques, which preclude serial measurements in the same animal, or indirect calorimetry, which require specialized facilities. On the other hand, TOH or deuterium oxide $\left(\mathrm{D}_{2} \mathrm{O}\right)$ dilution techniques allow serial measurements to be made utilizing less sophisticated equipment. All water-tracer techniques are based on the inverse relationship between water and fat in the EB (Reid et al. 1955). Consequently the precision of EB fat estimation is dependent on how precisely live weight, GF (and GW) and EBW can be determined. In all these applications live weight itself is the major independent variable and final predictions of EB fat are, therefore, very much dependent on the relationship between EB fat and live weight alone (Dunshea et al. 1988 a). Variable GF, in addition to containing considerable and variable amounts of water, detract from relationships between live weight and EB fat and attempts are generally made to minimize GF through fasting.

Until recently, estimates of TBW were almost exclusively obtained by taking a single blood sample, generally between 6 and $8 \mathrm{~h}$ after injection of TOH or $\mathrm{D}_{2} \mathrm{O}$. As the animals were often fasted for up to $48 \mathrm{~h}$ before the water tracer was given, water turnover was low and estimates were close to actual TBW. Nevertheless, these techniques result in overestimates of TBW of the order of $2-9 \%$ in fasted ruminants (Panaretto, 1963; Panaretto \& Till, 1963; Searle, 1970; Trigg et al. 1978; Dunshea et al. 1988 b) and 13\% in unfasted cattle (Carnegie \& Tulloh, 1968). However, Foot et al. (1979), like us, felt that fasting was undesirable in lactating animals, and so attempted to estimate body composition in lactating ewes using a similar protocol to the traditional methods but omitted the preinjection fast. As water turnover in these sheep varied between 5 and $11 \mathrm{~kg} / \mathrm{d}$, the 
regression equation relating $\mathrm{TBW}$ to $\mathrm{TOH}$ space had an intercept significantly greater than zero, a slope of 0.73 and a correlation which was not as close as that normally observed (r 0.951$)$.

An alternative to this approach is to take blood samples over a number of days and extrapolate the best-fit single exponential to time zero. In cases where the two techniques were compared, this one-pool kinetic method always overestimated TBW to a lesser degree than did the single-sample method, although the correlations between the two were not as high as would be hoped for (Foot et al. 1979; Cowan et al. $1980 \mathrm{~b}$; present study). Also, although the one-pool kinetic technique does provide a better estimate of TBW there still exists an unknown and possibly large amount of water in the gut.

Gut fill was correlated with DMI in lactating ewes (Cowan et al. 1980 b) and goats (Dunshea et al. 1988a), but the precision of these estimates alone was inadequate for prediction purposes (RSD 2.4 and $1.6 \mathrm{~kg}$ in these two studies respectively). Therefore, when a two-pool open model was fitted to $\mathrm{D}_{2} \mathrm{O}$-enrichment curves after a single injection of $\mathrm{D}_{2} \mathrm{O}$ to lambs (Robelin, 1977) and growing cattle (Byers, 1979), an alternative approach for measuring body water became apparent. The two water pools generated from such a model were found by Byers (1979) to be highly correlated with, and of the same magnitude as, EBW and GW. We have also found that the two pools determined from TOH kinetics in lactating goats approximated EBW and GW (Table 1, equations 2 and 3, $r 0.982$ and 0.804 respectively; Dunshea et al. 1988 a). Furthermore, when DMI was included as an additional independent predictor of GF the correlation was even better (Table 1, equation 4, $r .951$ ).

Although Byers (1979) and ourselves were able accurately to predict EBW and GW using the two-pool model, some other attempts to correlate GW with any of the pools generated during the fitting of models to $\mathrm{D}_{2} \mathrm{O}$-enrichment curves in ruminants have been less successful, for various reasons. Ferrell \& Jenkins (1984) stanchioned their cattle overnight without food or water before infusing $\mathrm{D}_{2} \mathrm{O}$. These cattle were not slaughtered until $3 \mathrm{~d}$ later, during which time increases in GF would have occurred as the animals had access to food and water. Likewise, the cattle studied by Odwongo et al. (1984) were not slaughtered until 11-15 d after the $\mathrm{D}_{2} \mathrm{O}$ infusion, sufficient time for substantial changes in $\mathrm{GW}$ and $\mathrm{GF}$ to occur. Arnold et al. (1985) concluded that the two-pool model did not offer any improvement over the one-pool model in predicting body composition in growing cattle. This is not surprising, since the one-pool model should be satisfactory under the conditions reported by Arnold et al. (1985) where GW and GF were small and relatively constant proportions of live weight. GF and GW are greater proportions of live weight in lactating goats, hence the ability to discriminate between EBW and GW becomes increasingly important. Under these conditions the two-pool model should be more effective than the one-pool model in describing water distribution. This is borne out by our inability to detect any differences in EB fat using the one-pool model of TOH kinetics due to both live weight and estimated TBW remaining unchanged over the course of the study. However, it is obvious from the estimates of energy balance that there must have been considerable changes in EB fat, particularly between days 10 and 39 of lactation.

Average body fat mobilization over the period days 10-39 of lactation in the present study was estimated using the two-pool model of TOH kinetics to be $59 \mathrm{~g} / \mathrm{d}$, which is similar to that observed in primiparous goats over the same stage of lactation (Dunshea et al. 1989). Other researchers using water tracer techniques have reported similar estimates of body fat mobilization in lactating ewes. Foot et al. (1979) used the single-sample method for determining $\mathrm{TOH}$ space in Greyface ewes fed at various levels. Calculations from their body composition values provide estimates of 65 and $27 \mathrm{~g}$ fat mobilized/d between days 6 and 34 and days 34 and 83 respectively. Vermorel et al. (1987) employed the one-pool kinetic model to estimate $\mathrm{D}_{2} \mathrm{O}$ space and, hence, EB fat in low-producing dairy ewes. 
Estimated fat mobilization in these ewes was $41 \mathrm{~g} / \mathrm{d}$ between days 3 and 42 of lactation. The most comprehensive studies of fat mobilization during lactation in small ruminants have been done using comparative slaughter techniques in sheep. Using this approach Cowan et al. (1981) found that high-yielding ewes fed ad lib. on a diet containing either 116 or $143 \mathrm{~g}$ crude protein $/ \mathrm{kg}$ DM mobilized approximately $140 \mathrm{~g}$ fat $/ \mathrm{d}$ between days 6 and 42 of lactation. Even greater fat mobilization $(340 \mathrm{~g} / \mathrm{d})$ was observed in ewes fed to deposit fat during mid- to late gestation and fed $a d$ lib. on a low-concentrate diet during early lactation (Cowan et al. 1980 a). In contrast, there did not appear to be any relation between EB fat at day 10 of lactation and fat mobilization over the next 4 weeks in our goats.

It is apparent that relying on live-weight changes alone provides little information on changes in body composition in unfasted lactating goats. During the early part of lactation the goats were in negative energy balance and were mobilizing EB fat. However, as lactation advanced the goats increased DMI and GF such that live weight did not change, similar to the trends observed in primiparous goats over the same stage of lactation (Dunshea et al. 1989). This is also consistent with the work of Flatt et al. (1965) who used indirect calorimetry to demonstrate that it was possible for a dairy cow to lose up to $2 \mathrm{~kg} \mathrm{fat} / \mathrm{d}$ during early lactation with no discernible change in live weight. Cowan et al. $(1980 \mathrm{~b})$ observed a large increase in DMI over the first week of lactation, followed by a more gradual increase over the next 6 weeks in lactating ewes. These authors used DMI to predict GF and estimated that in the period between 1 and 7 weeks post-partum the loss of live weight appeared to be less than that of EB-weight.

Previously, we found significant correlations between water turnover (WTO) and both DMI and milk yield in seventeen lactating goats (Dunshea et al. 1988a). Those values included the estimates of WTO from the ten goats slaughtered at day 77 post-partum in the present study. However, when the data set was expanded to include more measurements early in lactation, these relationships became less apparent. Apart from individual variation in water intake, this probably reflects independent changes in DMI and milk yield, both of which may influence WTO. Nevertheless, WTO was greatest at day 38 of lactation when both milk production and DMI were high.

If the present, indirectly-obtained estimates of EB fat mobilized are accurate then they should correlate with, and be of the same order as, averge energy balance over the period between estimates of body composition. This is verified in Fig. 2 where the relationship between average energy balance and changes in body energy stored as fat, estimated using the two-pool model of TOH kinetics, are shown. On the other hand, there was no correlation between average energy balance and changes in body energy as fat estimated from the one-pool model of TOH kinetics. However, Vermorel et al. (1987) found energy exchanges measured by indirect calorimetry gave similar derivations of efficiency of utilization of $\mathrm{ME}$ for lactation $\left(k_{1}\right)$ and energy for maintenance, as obtained by serial estimates of body composition using the one-pool model of $\mathrm{D}_{2} \mathrm{O}$ kinetics in lactating ewes.

The present findings demonstrate that fat mobilization can occur in goats fed ad lib. during early lactation, allowing them to perform closer to their potential for milk production. We have also demonstrated the value of using a two-pool model of TOH kinetics to provide serial estimates of body composition in lactating goats. However, a shortcoming of a technique based on static measurement of body composition at points in time is that it provides no knowledge of the current energy status of the animal. In contrast, plasma NEFA concentrations and entry rate should provide a more immediate and dynamic assessment of energy balance and in a companion paper we evaluate the efficacy of using NEFA kinetics as an index of energy status in the same goats (Dunshea et al. 1990). 
The authors wish to thank Mr K. D. Chandler, Miss R. Fitzpatrick and Miss R. Vavala for technical assistance and care of the animals. F. R.D. was supported by a grant from the Australian Dairy Research Committee.

\section{REFERENCES}

Agricultural Research Council (1980). The Nutrient Requirements of Ruminant Livestock. Slough : Commonwealth Agricultural Bureaux.

Armstrong, D. G. \& Blaxter, K. L. (1965). Effects of acetic and propionic acids on energy retention and milk secretion in goats. In Energy Metabolism, pp. 59-72 [K. L. Blaxter, editor]. London: Academic Press.

Arnold, R. N., Hentges, R. J. \& Trenkle, A. (1985). Evaluation of the use of deuterium oxide dilution technique for determination of body composition of beef steers. Journal of Animal Science 60, 1188-1200.

Bines, J. A. (1979). Voluntary feed intake. In Feeding Strategies for the High Yielding Dairy Cow, pp. 23-28 [W. H. Broster and H. Swan, editors]. London: Granada Press.

Byers, F. M. (1979). Measurement of protein and fat accretion in growing beef cattle through isotope dilution procedures. Ohio Beef Cattle Research Progress Report Series 79-1, pp. 36-47. Wooster, Ohio: Ohio Agricultural Research Development Centre.

Carnegie, A. B. \& Tulloh, N. M. (1968). The in vivo determination of body water space in cattle using the tritium dilution technique. Proceedings of the Australian Society of Animal Production 7, 308-313.

Chew, B. P., Eisenman, J. R. \& Tanaka, T. S. (1984). Arginine infusion stimulates prolactin, growth hormone, insulin and subsequent lactation in pregnant dairy cows. Journal of Dairy Science 67, 2507-2518.

Corbett, J. L., Farrell, D. J., Leng, R. A., McClymont, G. L. \& Young, B. A. (1971). Determination of the energy expenditure of penned and grazing sheep from estimates of carbon dioxide entry rate. British Journal of Nutrition 26, 277-291.

Cowan, R. T., Robinson, J. J., McDonald, I. \& Smart, R. (1980a). Effects of body fatness at lambing and diet in lactation on body tissue loss, feed intake and milk yield of ewes in early lactation. Journal of Agricultural Science, Cambridge 95, 497-514.

Cowan, R. T., Robinson, J. J., McHattie, I. \& Fraser, C. (1980 b). The prediction of body composition in live ewes in early lactation from live weight and estimates of gut contents and total body water. Journal of Agricultural Science, Cambridge 95, 515-522.

Cowan, R. T., Robinson, J. J., McHattie, 1. \& Pennie, K. (1981). Effects of protein concentration in the diet on milk yield, change in body composition and the efficiency of utilization of body tissues for milk production in ewes. Animal Production 33, $111-120$.

Dunshea, F. R., Bell, A. W., Chandler, K. D. \& Trigg, T. E. (1988a). A two pool model of tritiated water kinetics to predict body composition in unfasted lactating goats. Animal Production 47, 435-445.

Dunshea, F. R., Bell, A. W. \& Trigg, T. E. $(1988 \mathrm{~b})$. Relations between plasma non-esterified fatty acid metabolism and body tissue mobilization during chronic undernutrition in goats. British Journal of Nutrition 60, 633-644.

Dunshea, F. R., Bell, A. W. \& Trigg, T. E. (1989). Relations between plasma non-esterified fatty acid metabolism and body fat mobilization in primiparous lactating goats. British Journal of Nuirition 62, $51-61$.

Dunshea, F. R., Bell, A. W. \& Trigg, T. E. (1990). Non-esterified fatty acid and glycerol kinetics and fatty acid re-esterification in goats during early lactation. British Journal of Nutrition 64, 133-145.

Ferrell, C. L. \& Jenkins, T. G. (1984). Relationships among various body components of mature cows. Journal of Animal Science 58, 222-233.

Flatt, W. P., Moore, L. P., Hooven, N. W. \& Plowman, R. D. (1965). Energy metabolism studies with a high producing dairy cow. Journal of Dairy Science 48, 797 Abstr.

Foot, J. Z. \& Greenhalgh, J. F. D. (1970). The use of deuterium oxide space to determine the amount of body fat in pregnant Blackface ewes. British Journal of Nutrition 24, 815-825.

Foot, J.Z., Skedd, E. \& McFarlane, D. N. (1979). Body composition in lactating sheep and its indirect measurement in the live animal using tritiated water. Journal of Agricultural Science, Cambridge 92, 69-81.

Hecker, J. F. (1974). Experimental Surgery on Small Ruminants. London: Butterworths.

Linzell, J. L. (1966). Infusion and blood sampling techniques for use in minimally restrained goats. Journal of Physiology 186, 79P-81P.

Ministry of Agriculture, Fisheries and Food (1975). Energy Allowances and Feeding Systems for Ruminants. Technical Bulletin no. 33. London: H.M. Stationery Office.

Moe, P. W. (1981). Energy metabolism of dairy cattle. Journal of Dairy Science 64, 1120-1139.

Odwongo, W. O., Conrad, H. R. \& Staubus, A. E, (1984). The use of deuterium oxide for the prediction of body composition in live dairy eattle. Journal of Nutrition 114, 2127-2137.

Panaretto, B. A. (1963). Body composition in vivo. I. The estimation of total body water with antipyrine and the relation of total body water to total body fat in ruminants. Australian Journal of Agricultural Research 14, 594601 . 
Panaretto, B. A. \& Till, A. R. (1963). Body composition in vivo. II. The composition of mature goats and its relationship to the antipyrine, tritiated water, and $\mathrm{N}$-acetyl-4-aminoantipyrine spaces. Australian Journal of Agricultural Research 14, 926-943.

Reid, J. T., Wellington, G. H. \& Dunn, H. O. (1955). Some relationships among the major chemical components of the bovine body and their application to nutritional investigations. Journal of Dairy Science 38, $1344-1359$.

Robelin, J. (1977). Estimation in vivo de la composition corporelle des agneaux à partir de l'espace de diffusion de l'eau lourde. (In vivo prediction of lamb body composition using heavy water space) Annales de Biologie Animale, Biochimie et Biophysique 17, 95-105.

Ross, G. J. S. (1980). MLP: Maximum Likelihood Program (Version 3.06). Rothamsted: Rothamsted Experimental Station.

Ryan, T. A. Jr, Joiner, B. L. \& Ryan, B. F. (1985). Minitab: Version 5.1. Massachusetts: Duxbury Press.

Searle, T. W. (1970). Body composition in lambs and young sheep and its prediction in vivo from tritiated water space and body weight. Journal of Agricultural Science, Cambridge 74, 357-362.

Shipley, R. A. \& Clark, R. E. (1972). Tracer Methods for in vivo Kinetics. New York: Academic Press.

Statistical Analysis System (1982). SAS User's Guide: Statistics. Cary, NC: SAS Institute Inc.

Steine, T. A. (1975). Faktorar med innverknad pa okonomisk viktage eigenskaper hos geit. (Factors affecting economically important traits in goats.) Meldinger fra Norges Landbrukshogskole 54, 1-30.

Trigg, T. E., Domingo, E. A. \& Topps, J. H. (1978). A comparison of three different isotopic methods for measuring body components of sheep. Journal of the Science of Food and Agriculture 29, 1007-1016.

Tyrell, H. F. \& Reid, J. T. (1965). Prediction of the net energy value of cow's milk. Journal of Dairy Science 48, $1215-1223$.

Vermorel, M., Bocquier, F., Vernet, J. \& Brelurut, A. (1987). Mobilization and reconstitution of body reserves in dairy ewes studied by indirect calorimetry and $\mathrm{D}_{2} \mathrm{O}$ dilution technique. In Energy Metabolism of Farm Animals, pp. 314-317 [P. W. Moe, H. F. Tyrell and P. J. Reynolds, editors]. New Jersey: Rowman and Littlefield. 